\title{
$B$-site substituted solid solutions on the base of sodium-bismuth titanate
}

\author{
V. M. Ishchuk*, L. G. Gusakova*, N. G. Kisel*, D. V. Kuzenko*, \\ N. A. Spiridonov* and V. L. Sobolev ${ }^{\dagger+*}$ \\ *Science \& Technology Center 'Reactivelectron' of the Ukrainian National \\ Academy of Sciences, Donetsk 83049, Ukraine \\ †Physics Department, South Dakota School of Mines \& Technology \\ Rapid City, SD 57701, USA \\ tvladimir.sobolev@sdsmt.edu
}

Received 27 June 2016; Accepted 18 September 2016; Published 25 October 2016

\begin{abstract}
The paper presents results of studies of the formation of phases during the solid-state synthesis in the $\left[\left(\mathrm{Na}_{0.5} \mathrm{Bi}_{0.5}\right)_{0.80} \mathrm{Ba}_{0.20}\right]\left(\mathrm{Ti}_{1-y} \mathrm{~B}_{y}\right) \mathrm{O}_{3}$ system of solid solutions with $B$-site substitutions. The substitutions by zirconium, tin and ion complexes $\left(\mathrm{In}_{0.5} \mathrm{Nb}_{0.5}\right)$ and $\left(\mathrm{Fe}_{0.5} \mathrm{Nb}_{0.5}\right)$ have been studied. It has been found that the synthesis is a multi-step process associated with the formation of a number of intermediate phases (depending on the compositions and calcination temperatures). Single-phase solid solutions have been produced at the calcination temperatures in the interval $1000-1100^{\circ} \mathrm{C}$. An increase in the substituting ions concentration leads to a linear increase of the crystal cell size. At the same time, the tolerance factor gets reduced boosting the stability of the antiferroelectric phase as compared to that of the ferroelectric phase.

Keywords: $\left(\mathrm{Na}_{0.5} \mathrm{Bi}_{0.5}\right) \mathrm{TiO}_{3}$; solid solution; ions substitution; solid-state synthesis; phase transition.
\end{abstract}

\section{Introduction}

Piezoelectric materials constitute numerous components used in communication systems, defense systems, industrial automation, medical diagnostics, energy storage and harvesting and information technology. Lead zirconate titanate (PZT), lead magnesium niobate and lead zinc niobate-based solid solutions are the materials of choice in high performance piezoelectric applications since their largest values of piezoelectric parameters among all piezoelectric compounds are known at present.

Worldwide environmental considerations demand a possibility of removal of lead-based materials from majority of applications. This circumstance has created urgency for finding alternatives to lead-containing piezoelectric substances and generated an avalanche of publications devoted to manufacturing and investigations of properties of wide range of such materials (since it is impossible to site all reviews devoted to the subject, we mention just some of them ${ }^{1-7}$ ).

The need to replace lead-containing substances by the lead-free materials has raised an interest in the $\left(\mathrm{Na}_{0.5} \mathrm{Bi}_{0.5}\right)$ $\mathrm{TiO}_{3}$-based piezoceramics. The most investigated among the NBT-based compounds are the solid solutions with compositions $\quad(1-x)\left(\mathrm{Na}_{0.5} \mathrm{Bi}_{0.5}\right) \mathrm{TiO}_{3}-x \mathrm{BaTiO}_{3} \quad$ (NBT$100 x \mathrm{BT})^{3,8-10}$, whose promising piezoelectric behavior is credited to the existence of a morphotropic phase boundary (MPB) similar to that of $\mathrm{PZT}^{1,2}$ for compositions $x=0.05-$ 0.07. At the same time, these solid solutions have a few substantial disadvantages, such as low temperature destruction of the polar ferroelectric (FE) state (of the order of 130$150^{\circ} \mathrm{C}$ ) in the solid solutions from the morphotropic region of the diagram of phase states of NBT-100xBT and low values of the piezoelectric modulus $d_{33}(160-180 \mathrm{pC} / \mathrm{N})$. Review of recent investigations (up to 2016) of the NBT-100xBT solid solutions is given in Ref. 7.

In the majority of publications devoted to investigations of the NBT-based solid solutions, these compounds were obtained by substitutions in the $A$-site of the perovskite crystal lattice. In all cases, such substitution led to decrease in the temperature of the ferroelectric-antiferroelectric (FEAFE) phase transition of the prime NBT. Besides, large values of the coercive field in the NBT-based solid solutions made the polarization of samples to be very difficult. These factors limited the possibility of application of NBT-based materials and made the replacement of PZT by NBT-based solid solutions impossible as of today.

It has been known for quite some time that the large values of piezoelectric parameters in lead-containing piezoelectric substances have been achieved because of the $B$-site substitutions. Solid solutions $\mathrm{PbZrO}_{3}-\mathrm{PbTiO}_{3}, \mathrm{~Pb}\left(\mathrm{Mg}_{1 / 3} \mathrm{Nb}_{2 / 3}\right) \mathrm{O}_{3}-\mathrm{PbTiO}_{3}$, $\mathrm{Pb}\left(\mathrm{Zn}_{1 / 3} \mathrm{Nb}_{2 / 3}\right) \mathrm{O}_{3}-\mathrm{PbTiO}_{3}$ are a good example of this statement.

The aim of our studies is to investigate the influence of ionic substitutions into the $B$-sites of the crystal lattice of the NBT-based solid solutions on the relative stability of the FE and AFE states and to explore the physical factors promoting the expansion of the temperature range of existence of the $\mathrm{FE}$

This is an Open Access article published by World Scientific Publishing Company. It is distributed under the terms of the Creative Commons Attribution 4.0 (CC-BY) License. Further distribution of this work is permitted, provided the original work is properly cited. 
state. This report contains the results of studies of the influence of titanium substitution by different ions and ion complexes (such as zirconium, tin, $\left(\mathrm{In}_{0.5} \mathrm{Nb}_{0.5}\right),\left(\mathrm{Fe}_{0.5} \mathrm{Nb}_{0.5}\right)$ ) on the process of formation of solid solutions and the phase transitions in the synthesized compounds.

\section{Experimental Methods}

NBT-based compounds were synthesized using a conventional solid-state synthesis method. Reagent grade oxides and carbonates of corresponding metals were used as starting materials, which were mixed, in the appropriate stoichiometry (except for $\mathrm{Bi}_{2} \mathrm{O}_{3}$, which was taken in $0.5 \mathrm{wt} . \%$ excess) by ball milling for $12 \mathrm{~h}$. The mixed powders were calcined at various temperatures in the interval $700-1100^{\circ} \mathrm{C}$ for durations from 2 to $20 \mathrm{~h}$.

The phase analysis was carried out using a DRON-3 X-ray diffractometer in the Bragg-Brentano geometry, using $\mathrm{CuK} \alpha$ radiation $(\lambda=1.5418 \AA$ ), Ni-filter for incident beam and graphite monochromator in the diffraction beam (the angular range was $20^{\circ} \leq 2 \theta \leq 90^{\circ}$, the scan step was $0.02^{\circ}$, the accumulation time at each point was $1 \mathrm{~s}$ ). Intermediate phases were identified using ASTM-library.

The samples for measurements of dielectric constant and crystal lattice parameters were manufactured by calcination at $900^{\circ} \mathrm{C}$ for $6 \mathrm{~h}$. The synthesized powders were axially pressed into disks with a diameter of $12 \mathrm{~mm}$ and a thickness of $1 \mathrm{~mm}$. The further sintering of ceramic samples was performed at $1200^{\circ} \mathrm{C}$ for $2 \mathrm{~h}$. The process was carried out in closed alundum crucibles with a filling having the NBT composition to avoid losses of the highly volatile components. Sintered samples represented a completely singlephase solid solution.

A fire-on silver paste was used for electrodes.

Temperature dependencies of the dielectric parameters were measured at $1 \mathrm{kHz}$ by QuadTech 7600 LCR meter. A standard Sawyer-Tower circuit at $10^{-2} \mathrm{~Hz}$ was used for observation of D-E hysteresis loops.

\section{Results of the Solid-State Reactions Study}

In the PZT solid solutions, one of the components $\left(\mathrm{PbTiO}_{3}\right)$ is $\mathrm{FE}$ and the other one $\left(\mathrm{PbZrO}_{3}\right)$ is AFE. The increase of concentration of zirconium that substitutes titanium in the crystal lattice, leads to stabilization of nonpiezoelectric AFE phase. ${ }^{11,12}$ There are very few reports on the NBT-based solid solutions with the substitution of zirconium for titanium, in the literature (see, for example, Refs. 13-17). Nonetheless, it has been expected that in this case, zirconium substitutions will also stabilize the AFE state. Therefore, for the investigation of influence of the substitution of zirconium for titanium, we have chosen the $\left[\left(\mathrm{Na}_{0.5} \mathrm{Bi}_{0.5}\right)_{0.8} \mathrm{Ba}_{0.2}\right] \mathrm{TiO}_{3}$ as a base solid solution. This compound is located in the region of the FE phase stability in the diagram of the phase states of the
$\left[\left(\mathrm{Na}_{0.5} \mathrm{Bi}_{0.5}\right)\right] \mathrm{TiO}_{3}-\mathrm{BaTiO}_{3}$ system and is situated far beyond the morphotropic region. ${ }^{9,18,19}$

\section{1. $\left[\left(\mathrm{Na}_{0.5} \mathrm{Bi}_{0.5}\right)_{1-x} \mathrm{Ba}_{x}\right] \mathrm{TiO}_{3}$ solid solutions}

Here we present the results of studies on the formation of phases in the $\left[\left(\mathrm{Na}_{0.5} \mathrm{Bi}_{0.5}\right)_{1-x} \mathrm{Ba}_{x}\right] \mathrm{TiO}_{3}$ system for the subsequent comparison. The introduction of barium ions in the crystal lattice has led to a complication of the phase formation process in the system of initials components compared to the pure NBT (Figs. 1(a) and 1(b)).

When the mixture of the starting components with $10 \mathrm{~mol}$. $\%$ of $\mathrm{BaTiO}_{3}$ was annealed at $700^{\circ} \mathrm{C}$ for $6 \mathrm{~h}$, the reaction mixture contained a large amount of the NBT-based solid solution against the initial oxides and carbonates, and the $\mathrm{BaTiO}_{3}$-based solid solution in a small amount. Intermediate phases in the form of bismuth titanate $\mathrm{Bi}_{12} \mathrm{TiO}_{20}$, sodium bismuth titanate $\mathrm{NaBiTi}_{6} \mathrm{O}_{14}$, barium titanate, $\mathrm{BaBi}_{4} \mathrm{TiO}_{15}$ and $\mathrm{BaBiO}_{2.77}$ (all in very small amounts) are also present in the products of the reaction. An increase in the calcination temperature to $800^{\circ} \mathrm{C}$ (with the same $6 \mathrm{~h}$ time) gave the reaction mixture in which the content of bismuth titanate $\mathrm{Bi}_{12} \mathrm{TiO}_{20}$ and sodium bismuth titanate $\mathrm{NaBiTi}_{6} \mathrm{O}_{14}$ decreased, $\mathrm{BaTiO}_{3}$ and $\mathrm{BaBiO}_{2.77}$ disappeared completely. Almost single-phase solid solution was formed after calcination at $900^{\circ} \mathrm{C}$.

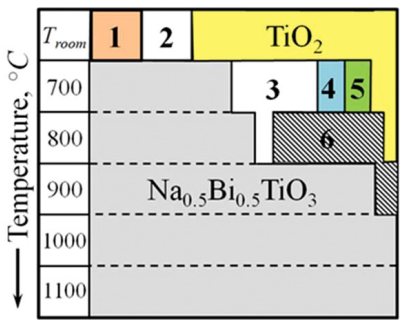

(a)

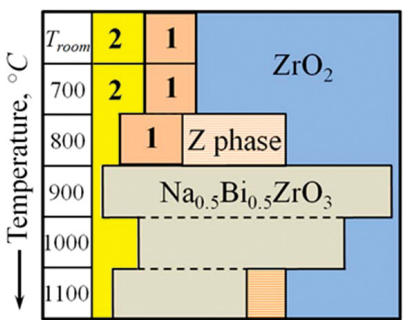

(c)

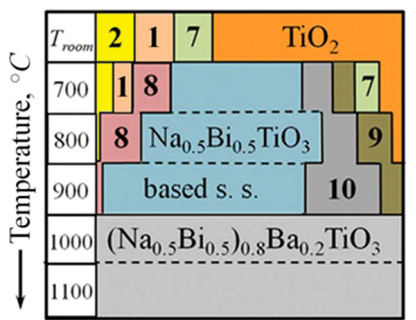

(b)

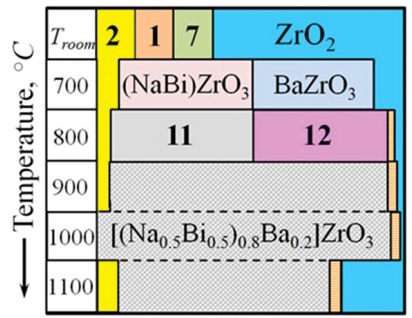

(d)
Fig. 1. Formation of phases during solid-state synthesis of (a) NBT; (b) $\left[\left(\mathrm{Na}_{0.5} \mathrm{Bi}_{0.5}\right)_{0.8} \mathrm{~B}_{0.2}\right] \mathrm{TiO}_{3}$; (c) $\left(\mathrm{Na}_{0.5} \mathrm{Bi}_{0.5}\right) \mathrm{ZrO}_{3}$ and (d) $\left[\left(\mathrm{Na}_{0.5} \mathrm{Bi}_{0.5}\right)_{0.8} \mathrm{~B}_{0.2}\right] \mathrm{ZrO}_{3}$. Intermediate phases: $1-\mathrm{Na}_{2} \mathrm{CO}_{3}, 2-$ $\mathrm{Bi}_{2} \mathrm{O}_{3}, 3-\mathrm{Bi}_{12} \mathrm{TiO}_{20}, 4-\mathrm{Na}_{2} \mathrm{Ti}_{6} \mathrm{O}_{13}, 5-\mathrm{Na}_{2} \mathrm{Ti}_{3} \mathrm{O}_{7}, 6-$ $\mathrm{Bi}_{4} \mathrm{Ti}_{3} \mathrm{O}_{12}, 7-\mathrm{BiCO}_{3}, 8-\mathrm{NaBiTi}_{6} \mathrm{O}_{14}, 9-\mathrm{BaBi}_{4} \mathrm{Ti}_{4} \mathrm{O}_{15}, 10-$ $\mathrm{BaTiO}_{3}$ based solid solutions, $11-(\mathrm{NaBi}) \mathrm{ZrO}_{3}$ based solid solutions, $12-\mathrm{BaZrO}_{3}$ based solid solutions. The time of calcination was $6 \mathrm{~h}$ for every temperature. 
When the barium content was increased to $x=0.2$, the sequence of phase formation at low calcination temperatures $\left(700-800^{\circ} \mathrm{C}\right)$ was analogous to the sequence of phase formation for the system with $x=0.1$. The complete formation of single-phase solid solution in this case required a higher temperature - about $1000^{\circ} \mathrm{C}$ (Fig. 1(b)).

\section{2. $\left(\mathrm{Na}_{0.5} \mathrm{Bi}_{0.5}\right)_{1-x} \mathrm{Ba}_{x} \mathrm{ZrO}_{3}$ solid solutions}

Let us first consider the synthesis process of the sodium bismuth zirconate $\left(\mathrm{Na}_{0.5} \mathrm{Bi}_{0.5}\right) \mathrm{ZrO}_{3}$ (NBZ) that does not contain barium. The formation of NBZ with slightly distorted perovskite lattice form the mixture of reagents $0.25 \cdot \mathrm{Na}_{2} \mathrm{CO}_{3}+(0.25+0.5$ wt. $\%) \cdot \mathrm{Bi}_{2} \mathrm{O}_{3}+\mathrm{ZrO}_{2}$ began at $800^{\circ} \mathrm{C}$. The new $Z$-phase was present in the final reaction mixture. Based on the $\mathrm{X}$-ray diffraction data, this $Z$-phase represents NBZ with the excess of $\mathrm{Bi}$ and deficiency of $\mathrm{Zr}$ in crystal structure. The NBZ became the primary phase after calcination at $900^{\circ} \mathrm{C}$ for $3 \mathrm{~h}$. Small amounts of $\mathrm{ZrO}_{2}$ and $\mathrm{Bi}_{2} \mathrm{O}_{3}$ were present in the final mixture. The $Z$-phase was not observed.

The content of sodium bismuth zirconate in the synthesis products decreased when the calcination temperature was increased up to $1000^{\circ} \mathrm{C}$ and/or when the synthesis time was increased. The results of chemical analysis showed that such situation was due to the volatility of sodium oxide (the bismuth loss was much lower). The schematic of formation of the sodium bismuth zirconate is presented in Fig. 1(c).

Substitution of barium ions for the $\left(\mathrm{Na}_{0.5} \mathrm{Bi}_{0.5}\right)$ ion complex in the $A$-sublattice lead to a few changes in the nature of phase transformations at solid-state reactions as compared to NBZ. In the mixture of starting components with the $\left(\mathrm{Na}_{0.5} \mathrm{Bi}_{0.5}\right)_{0.90} \mathrm{Ba}_{0.10} \mathrm{ZrO}_{3}$ formula, the reaction started at a lower temperature of $700^{\circ} \mathrm{C}$, and was accompanied by the formation of $\left(\mathrm{Na}_{0.5} \mathrm{Bi}_{0.5}\right) \mathrm{ZrO}_{3}, \mathrm{NBZ}$-based solid solutions and $\mathrm{BaZrO}_{3}$. The latter result is interesting and surprising since the formation of barium zirconate during the conventional solid-state synthesis takes place at the temperatures in the range of $1200-1300^{\circ} \mathrm{C}$ or higher. The reaction mixture also contained the starting components $\mathrm{ZrO}_{2}$ and $\mathrm{Bi}_{2} \mathrm{O}_{3}$ in quite large amounts. The share of NBZ-based solid solution increased when the calcination temperature was elevated up to $800^{\circ} \mathrm{C}$, and at the same time, the share of $\mathrm{BaZrO}_{3}$-based compound decreased. The following result was obtained at calcination of initial mixture of components at $900^{\circ} \mathrm{C}$ for $10 \mathrm{~h}$. The main product of the reaction was $\left(\mathrm{Na}_{0.5} \mathrm{Bi}_{0.5}\right)_{0.90} \mathrm{Ba}_{0.10} \mathrm{ZrO}_{3}$ compound that had small distortion of the perovskite crystal lattice. Small amounts of the $Z$-phase and $\mathrm{ZrO}_{2}$ were also present. The barium zirconate $\mathrm{BaZrO}_{3}$ was absent. The time not less than $20 \mathrm{~h}$ was needed to complete formation of the single-phase product at this temperature.

Additional annealing at the temperature increased up to $1100^{\circ} \mathrm{C}$ lead to the reduction of the share of $\left(\mathrm{Na}_{0.5} \mathrm{Bi}_{0.5}\right)_{0.90} \mathrm{Ba}_{0.10} \mathrm{ZrO}_{3}$ along with the appearance of the $\mathrm{Bi}_{2} \mathrm{O}_{3}$ and $\mathrm{ZrO}_{2}$ (basic components) which indicated the decomposition of the solid solution.

An increase in the barium content in $\left(\mathrm{Na}_{0.5} \mathrm{Bi}_{0.5}\right)_{1-x}$ $\mathrm{Ba}_{x} \mathrm{ZrO}_{3}$ led to a complication of the phase formation sequence at low temperatures (up to $900^{\circ} \mathrm{C}$ ), however, gave a higher yield of the final product after the synthesis at high temperatures (see Fig. 1(d)). When the combination of initial components corresponding to the composition $\left(\mathrm{Na}_{0.5} \mathrm{Bi}_{0.5}\right)_{0.80} \mathrm{Ba}_{0.20} \mathrm{ZrO}_{3}$ was calcined at $700^{\circ} \mathrm{C}$ the resulting mixture, contained $\left(\mathrm{Na}_{0.5} \mathrm{Bi}_{0.5}\right) \mathrm{ZrO}_{3}$-based solid solutions with tetragonal perovskite structure $(a=4.08 \AA$, $c=4.101 \AA$ ), $\quad \mathrm{BaZrO}_{3}$-based solid solutions with cubic structure $(a=4.186 \AA)$ and small amounts of the basic oxides $\mathrm{Bi}_{2} \mathrm{O}_{3}$ and $\mathrm{ZrO}_{2}$. Calcination in the temperature interval 900 $1000^{\circ} \mathrm{C}$ for $3 \mathrm{~h}$ was accompanied by the formation of the $\left(\mathrm{Na}_{0.5} \mathrm{Bi}_{0.5}\right)_{0.80} \mathrm{Ba}_{0.20} \mathrm{ZrO}_{3}$ solid solution with cubic perovskite structure (with the lattice parameter $a=4.125 \AA$ ). The $Z$-phase and oxides of $\mathrm{Bi}_{2} \mathrm{O}_{3}, \mathrm{ZrO}_{2}$ were present in small quantities after the heat treatment at $900^{\circ} \mathrm{C}$. The $Z$-phase and $\mathrm{ZrO}_{2}$ were observed after the calcination at $1000^{\circ} \mathrm{C}$. However, they disappeared when the synthesis time was increased. An increase of the calcination temperature to $1100^{\circ} \mathrm{C}$ for $3 \mathrm{~h}$ or an increase of the exposure time up to $24 \mathrm{~h}$ at $1000^{\circ} \mathrm{C}$ resulted in the reduction of the share of $\left(\mathrm{Na}_{0.5} \mathrm{Bi}_{0.5}\right)_{0.80^{-}}$ $\mathrm{Ba}_{0.20} \mathrm{ZrO}_{3}$, and the rise in the content of the initial oxides of $\mathrm{Bi}_{2} \mathrm{O}_{3}$ and $\mathrm{ZrO}_{2}$. The $\mathrm{Z}$-phase was present in very small amount. The perovskite lattice parameter, $a$, increased and became equal $4.131 \AA$. It should be noted that the increase of the barium content in solid solutions led to the growth of the share of the finished product $\left(\mathrm{Na}_{0.5} \mathrm{Bi}_{0.5}\right)_{1-x} \mathrm{Ba}_{x} \mathrm{ZrO}_{3}$ even though the high-temperature decomposition of solid solution took place.

The $Z$-phase disappeared after the additional calcination at $750^{\circ} \mathrm{C}$ for $6 \mathrm{~h}$. The contents of the $\left(\mathrm{Na}_{0.5} \mathrm{Bi}_{0.5}\right)_{0.80} \mathrm{Ba}_{0.20} \mathrm{ZrO}_{3}$ solid solution and $\mathrm{Bi}_{2} \mathrm{O}_{3}$ and $\mathrm{ZrO}_{2}$ remained almost unchanged. Cubic lattice parameter of the solid solution also stayed unchanged.

In all the cases when the synthesis was carried out at the temperatures below $700^{\circ} \mathrm{C}$, the following intermediates were present in the final mixture: $\mathrm{Bi}_{4} \mathrm{Ti}_{3} \mathrm{O}_{12}, \mathrm{Na}_{2} \mathrm{Ti}_{6} \mathrm{O}_{13}$, $\mathrm{Na}_{2} \mathrm{Ti}_{3} \mathrm{O}_{7}, \mathrm{Bi}_{2} \mathrm{Ti}_{2} \mathrm{O}_{7}, \mathrm{Ba}_{2} \mathrm{TiO}_{4}, \mathrm{BaTi}_{4} \mathrm{O}_{9}$ and $\mathrm{NaBiTi}_{6} \mathrm{O}_{14}$. The subsequent calcination at higher temperatures led to their disappearance.

\section{3. $\left[\left(\mathrm{Na}_{0.5} \mathrm{Bi}_{0.5}\right)_{0.80} \mathrm{Ba}_{0.20}\right]\left(\mathrm{Ti}_{1-y} \mathrm{Zr}_{y}\right) \mathrm{O}_{3}$ solid solutions}

The results of studies of the phase formation in solid solutions containing titanium and zirconium ions in the $B$-sites of the crystal lattice were considered using $\left[\left(\mathrm{Na}_{0.5} \mathrm{Bi}_{0.5}\right)_{0.80^{-}}\right.$ $\left.\mathrm{Ba}_{0.20}\right]\left(\mathrm{Ti}_{1-y} \mathrm{Zr}_{y}\right) \mathrm{O}_{3}(y=0.1)$ as an example. XRD analysis of the reaction product when the mixture of reagents (corresponding to the above formula) was sintered at $700^{\circ} \mathrm{C}$ for $6 \mathrm{~h}$ showed that it contained two solid solutions (in approximately equal amounts) on the basis of $\left[\left(\mathrm{Na}_{0.5} \mathrm{Bi}_{0.5}\right)\right.$, Ba] $\left(\mathrm{Ti}_{0.5} \mathrm{Zr}_{0.5}\right) \mathrm{O}_{3}$ with a cubic crystal structure and lattice 
parameters $a=3.90 \AA$ and $a=4.02 \AA$. The second of them contained more barium than the first and the first one contained less zirconium than the second did. $\mathrm{Bi}_{12} \mathrm{TiO}_{20}$, $\mathrm{Bi}_{2} \mathrm{Ti}_{2} \mathrm{O}_{7}$ and the $Z$-phase (defined earlier) were present. There was also some amount of the $\left[\left(\mathrm{Na}_{0.5} \mathrm{Bi}_{0.5}\right)_{0.80} \mathrm{Ba}_{0.20}\right]$ $\left(\mathrm{Ti}_{0.90} \mathrm{Zr}_{0.10}\right) \mathrm{O}_{3}$ compound (Fig. 2).

An increase in the synthesis temperature to $900^{\circ} \mathrm{C}$ led to disappearance of $\mathrm{ZrO}_{2}$ and the $\mathrm{Z}$-phase in the reaction mixture. Intermediate compound $\mathrm{Bi}_{12} \mathrm{TiO}_{20}$ was present in minor amounts at this temperature and it was preserved at a temperature of $1000^{\circ} \mathrm{C}$. After synthesis at $1000^{\circ} \mathrm{C}$ for $6 \mathrm{~h}$, the products of the reaction consisted in a mixture of solid solutions with lattice parameters $a=3.94 \AA$ (main product) and $4.00 \AA$. The share of the second solid solution decreased with an increase of the calcination temperature and the time of exposure. Single-phase cubic $\left[\left(\mathrm{Na}_{0.5} \mathrm{Bi}_{0.5}\right)_{0.80} \mathrm{Ba}_{0.20}\right]$ $\left(\mathrm{Ti}_{0.90} \mathrm{Zr}_{0.10}\right) \mathrm{O}_{3}$ solid solution with a lattice parameter of $3.960 \AA$ A was formed at $1100^{\circ} \mathrm{C}$.

The sequence of phases formed during synthesis process was somewhat more complicated when the zirconium content increased to $20 \%$. After calcination at $700^{\circ} \mathrm{C}$, two predominant (the same as that for $y=0.1$ ) solid solution were present. However, in addition to the original components, the barium carbonate $\mathrm{BaCO}_{3}$ and a new intermediate phase with the perovskite crystal structure $(a=4.35 \AA)$ were also detected. The $\mathrm{Bi}_{12} \mathrm{TiO}_{20}$ compound was also present (as in the case of $y=0.10$ ).

Appreciable amounts of $\mathrm{ZrO}_{2}$, as well $\mathrm{Bi}_{12} \mathrm{TiO}_{20}$ remained in the reaction products with an increase of the calcination temperature to $800^{\circ} \mathrm{C}$. Two solid solutions $\left[\left(\mathrm{Na}_{0.5} \mathrm{Bi}_{0.5}\right)_{0.80} \mathrm{Ba}_{0.20}\right]\left(\mathrm{Ti}_{0.90} \mathrm{Zr}_{0.10}\right) \mathrm{O}_{3}$ (with $a=3.94 \AA$ ) and $\left[\left(\mathrm{Na}_{0.5} \mathrm{Bi}_{0.5}\right) \mathrm{Ba}\right]\left(\mathrm{Ti}_{0.5} \mathrm{Zr}_{0.5}\right) \mathrm{O}_{3}$-based solid solution (with $a=$ $4.02 \AA$ ) were in a predominant amount. After calcinations at $900^{\circ} \mathrm{C}$ and $1000^{\circ} \mathrm{C}$ for $6 \mathrm{~h}$, the reaction products were a

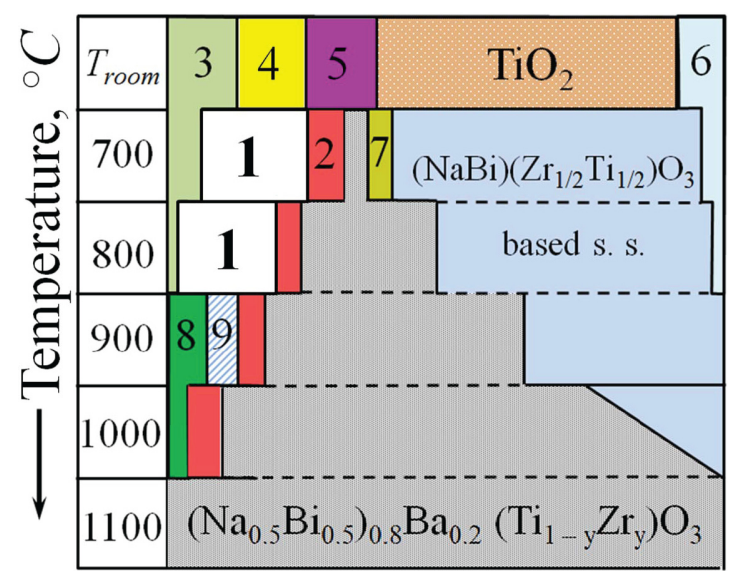

Fig. 2. Formation of phases during the solid-state synthesis of the $\left[\left(\mathrm{Na}_{0.5} \mathrm{Bi}_{0.5}\right)_{0.80} \mathrm{Ba}_{0.20}\right]\left(\mathrm{Ti}_{1-y} \mathrm{Zr}_{y}\right) \mathrm{O}_{3}$ solid solutions for $y=0.1$. Intermediate phases: $1-\mathrm{Bi}_{12} \mathrm{TiO}_{20}, 2-\mathrm{Ba}_{2} \mathrm{Ti}_{2} \mathrm{O}_{7}, 3-\mathrm{BaCO}_{3}$, $4-\mathrm{Bi}_{2} \mathrm{O}_{3}, 5-\mathrm{Na}_{2} \mathrm{CO}_{3}, 6-\mathrm{ZrO}_{2}, 7-Z$-phase, $8-\mathrm{Ba}_{2} \mathrm{TiO}_{4}$, $9-\mathrm{BaTi}_{4} \mathrm{O}_{9}$. Durations of calcination of the mixture of powders for each temperature are given in the text. mixture of solid solutions with lattice parameters $a=3.95 \AA$ and $a=4.02 \AA$. Single-phase solid solution with a lattice parameter $a=3.974 \AA$ was formed at $1100^{\circ} \mathrm{C}$. The decomposition of the solid solution did not take place at higher temperatures.

Increase in the zirconium content up to $30 \mathrm{~mol} . \%$ did not lead to significant changes in the pattern of the solid solutions formation.

Concluding the discussion of studies of the phase formation in NBT-based solid solutions containing zirconium, the decomposition of solid solutions at high temperatures should be discussed. In the case of the solid solutions on the basis of $\left(\mathrm{Na}_{0.5} \mathrm{Bi}_{0.5}\right) \mathrm{ZrO}_{3}$ without titanium, this decomposition took place while in the case of solid solutions $\left[\left(\mathrm{Na}_{0.5} \mathrm{Bi}_{0.5}\right)_{0.80} \mathrm{Ba}_{0.20}\right]\left(\mathrm{Ti}_{1-y} \mathrm{Zr}_{y}\right) \mathrm{O}_{3}$ with titanium the decomposition did not occur. In the first case, the synthesis of the solid solution did not end with $100 \%$ yield of the final product as well. It should be stressed that the insertion of Baions into the crystal structure of NBZ reduces the degree of the solid solution decomposition at high temperatures. As noted above, the decomposition of the solid solution was accompanied mainly by volatilization of sodium oxide.

The passage from NBT to NBZ was accompanied by an increase in the size of the crystal lattice due to the significant differences in the ionic radii of $\mathrm{Ti}^{4+}$ and $\mathrm{Zr}^{4+}$ ions ${ }^{20}(0.605$ and $0.72 \AA$, respectively). One must take into account two major factors. The ionic radius of $\mathrm{Na}^{+}$is less than the ionic radius of $\mathrm{Bi}^{3+}$ in the 12-coordination position of the perovskite crystal structure. Only one electron participates in the formation of bonds in the crystal lattice in the case of sodium, while there are three electrons in the case of bismuth. Due to these reasons, an increase in the interionic distance leads to a more rapid decrease in the bond energy for sodium than for bismuth. Therefore, the sodium volatilization and the solid solution decomposition at high temperatures have occurred in the case of zirconium solid solutions.

In the $\left[\left(\mathrm{Na}_{0.5} \mathrm{Bi}_{0.5}\right)_{0.80} \mathrm{Ba}_{0.20}\right]\left(\mathrm{Ti}_{1-y} \mathrm{Zr}_{y}\right) \mathrm{O}_{3}$ solid solutions, the change in the lattice parameters at substitution of zirconium for titanium (up to 30\%) has been much less (than for solid solutions considered before), so the sodium is coupled to the crystal structure stronger, and the high-temperature decomposition of the solid solution does not occur. Doe to this, as has been demonstrated above, the formation of the solid solution occurred at higher temperatures than in the absence of zirconium, and a solid-state synthesis process has been more complicated.

So, the synthesis of the $\left[\left(\mathrm{Na}_{0.5} \mathrm{Bi}_{0.5}\right)_{0.80} \mathrm{Ba}_{0.20}\right]\left(\mathrm{Ti}_{1-y} \mathrm{Zr}_{y}\right)$ $\mathrm{O}_{3}$ system of solid solutions is a multi-stage process that is accompanied by the formation of a number of intermediate phases (depending on the composition of the solid solution): $\mathrm{Bi}_{12} \mathrm{TiO}_{20}, \quad \mathrm{Bi}_{4} \mathrm{Ti}_{3} \mathrm{O}_{12}, \quad \mathrm{Na}_{2} \mathrm{Ti}_{6} \mathrm{O}_{13}, \quad \mathrm{Na}_{2} \mathrm{Ti}_{3} \mathrm{O}_{7}, \quad \mathrm{Bi}_{2} \mathrm{Ti}_{2} \mathrm{O}_{7}$, $\mathrm{Ba}_{2} \mathrm{TiO}_{4}, \mathrm{BaBi}_{4} \mathrm{Ti}_{4} \mathrm{O}_{15}, \mathrm{BaTi}_{4} \mathrm{O}_{9}, \mathrm{NaBiTi}_{6} \mathrm{O}_{14}$ and $\mathrm{BaZrO}_{3}$. Barium zirconate $\mathrm{BaZrO}_{3}$ has been detected in the reaction products after calcination at $700^{\circ} \mathrm{C}$ and has been present in the reaction mixture up to $850^{\circ} \mathrm{C}$. In the absence of titanium, 


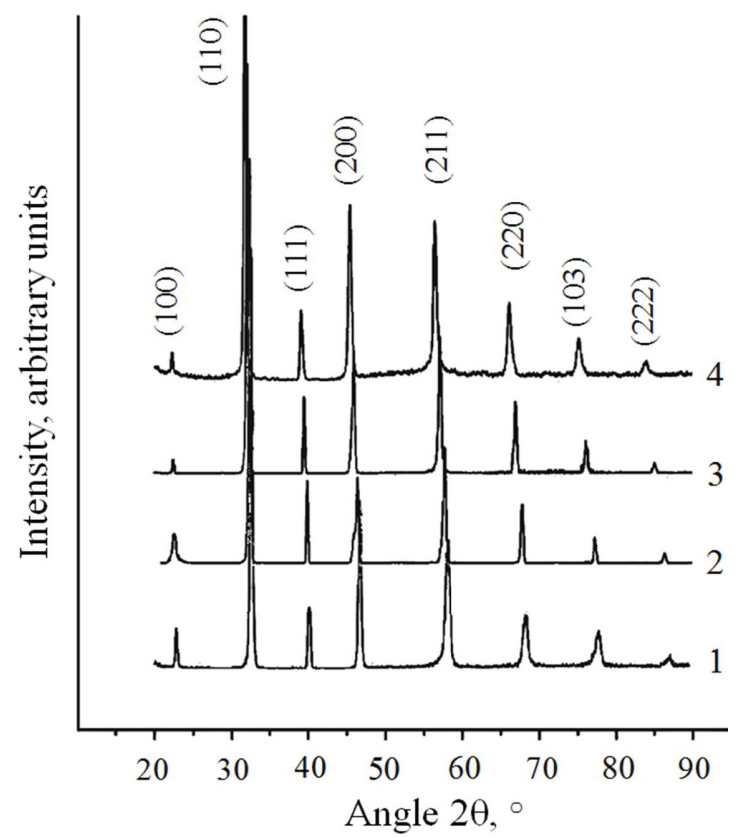

Fig. 3. X-ray patterns for $\left[\left(\mathrm{Na}_{0.5} \mathrm{Bi}_{0.5}\right)_{0.80} \mathrm{Ba}_{0.20}\right]\left(\mathrm{Ti}_{1-y} \mathrm{Zr}_{y}\right) \mathrm{O}_{3}$ solid solutions. Zr-content $(y): 1-0.00,2-0.05,3-0.10,4-0.30$.

high-temperature calcination has led to the degradation of the solid solutions. Barium activates the calcination process, reducing the onset temperature of the solid-state reaction in the system $\left[\left(\mathrm{Na}_{0.5} \mathrm{Bi}_{0.5}\right)_{1-x} \mathrm{Ba}_{x}\right] \mathrm{ZrO}_{3}$ compared to the NBZ system. Additional high-temperature annealing has led to the decomposition of solid solutions, if the $B$-sites of the crystal lattice contain $\mathrm{Zr}$ ions only. In solid solutions containing titanium, the solid solution decomposition at the additional high-temperature annealing has not been observed.

$\mathrm{X}$-ray diffraction patterns of ceramic samples of the $\left[\left(\mathrm{Na}_{0.5} \mathrm{Bi}_{0.5}\right)_{0.80} \mathrm{Ba}_{0.20}\right]\left(\mathrm{Ti}_{1-y} \mathrm{Zr}_{y}\right) \mathrm{O}_{3}$ solid solutions with 0.00 $\leq y \leq 0.30$ are shown in Fig. 3. All samples are single-phase.

$\mathrm{X}$-ray diffraction patterns for samples of the $\left[\left(\mathrm{Na}_{0.5} \mathrm{Bi}_{0.5}\right)_{0.80} \mathrm{Ba}_{0.20}\right]\left(\mathrm{Ti}_{1-y} \mathrm{~B}_{y}\right) \mathrm{O}_{3}$ solid solutions with the same content of substitutions $(0.00 \leq y \leq 0.30)$ of $\mathrm{Sn}$, $\left(\mathrm{In}_{0.5} \mathrm{Nb}_{0.5}\right)$ and $\left(\mathrm{Fe}_{0.5} \mathrm{Nb}_{0.5}\right)$ look identical to the one shown in Fig. 3 for single-phase samples.

\subsection{Sn-substituted $\left[\left(\mathrm{Na}_{0.5} \mathrm{Bi}_{0.5}\right)_{0.8} \mathrm{Ba}_{0.2}\right]\left(\mathrm{Ti}_{1-x} \mathrm{Sn}_{x}\right) \mathrm{O}_{3}$ solid solutions}

The synthesis process of $\left(\mathrm{Na}_{0,5} \mathrm{Bi}_{0,5}\right) \mathrm{TiO}_{3}$-based solid solutions with substitutions of tin for titanium is simpler than in the case of zirconium substitutions. This is due to the smaller ionic radius of $\mathrm{Sn}^{4+}$ compared to the ionic radius of $\mathrm{Zr}^{4+}$.

Synthesis of the $\left[\left(\mathrm{Na}_{0.5} \mathrm{Bi}_{0.5}\right)_{0.8} \mathrm{Ba}_{0.2}\right]\left(\mathrm{Ti}_{1-y} \mathrm{Sn}_{y}\right) \mathrm{O}_{3}$ compound at $800^{\circ} \mathrm{C}$ was accompanied by the formation of solid solutions with the pseudocubic perovskite crystal structure and the lattice parameters $a=3.93 \AA$ for $y=0.1$ and $a=$ $3.953 \AA$ for $y=0.2$, as well as by the formation of solid solution with a fluorite-type structure $(a=5.28 \AA)$. The predominant phase in the reaction product was the first solid solution. The amount of solid solution with the fluorite-type structure increased with increasing value of $y$. Additional solid solution with the perovskite crystal structure and $a=$ $4.01 \AA$ was also present in the reaction product. Based on the difference in the sizes of titanium and tin ions, it can be assumed that the first solid solution with the perovskite structure was formed by the substitution of tin ions for titanium in $\left[\left(\mathrm{Na}_{0.5} \mathrm{Bi}_{0.5}\right)_{0.8} \mathrm{Ba}_{0.2}\right] \mathrm{TiO}_{3}$. The second perovskite compound was formed with the substitution of titanium ions for tin ions in $\left[\left(\mathrm{Na}_{0.5} \mathrm{Bi}_{0.5}\right)_{0.8} \mathrm{Ba}_{0.2}\right] \mathrm{SnO}_{3}$.

The content of the phase with the fluorite-type crystal structure in the reaction mixture decreased approximately to $5 \%$ when $y=0.1$ and to $10 \%$ for $y=0.2$ when the calcination temperature increased to $900^{\circ} \mathrm{C}$. The main product of the reaction in both cases was the solid solution with the perovskite structure and $a=3.93 \AA$ for $y=0.1$ and $a=3.953 \AA$ for $y=0.20$. The second solid solution with the perovskite structure was present in the amount of 5-7\%. The tin oxide $\mathrm{SnO}_{2}$ in minor amounts $(2-3 \%)$ was also present.

Completion of the formation of single-phase solid solution depended on the tin content and occurred when the calcination was carried out at the temperatures in the interval of $1000-1100^{\circ} \mathrm{C}$ for $2 \mathrm{~h}$.

\section{5. $\left[\left(\mathrm{Na}_{0.5} \mathrm{Bi}_{0.5}\right)_{0.8} \mathrm{Ba}_{0.2}\right](\mathrm{Ti}, \mathrm{Zr}) \mathrm{O}_{3}$-based solid solutions with substitutions of $\left(\mathrm{In}_{0.5} \mathrm{Nb}_{0.5}\right)$}

Calcination of the mixture of starting components $\mathrm{Bi}_{2} \mathrm{O}_{3}$, $\mathrm{TiO}_{2}, \mathrm{Na}_{2} \mathrm{CO}_{3}, \mathrm{BaCO}_{3}, \mathrm{In}_{2} \mathrm{O}_{3}$ and $\mathrm{Nb}_{2} \mathrm{O}_{5}$ at $700^{\circ}$ for $1 \mathrm{~h}$ was accompanied by the formation of such intermediate compounds as $\mathrm{Bi}_{12} \mathrm{TiO}_{20}$ (the main reaction product) and NBTbased solid solution (at the starting stage). Increase in the calcination dwell time led to the growth of the share of the latter compound.

All starting components, excluding $\mathrm{In}_{2} \mathrm{O}_{3}$, were completely consumed when the calcination temperature increased to $800^{\circ} \mathrm{C}$ and new additional intermediate compounds such as $\mathrm{NaBiTi}_{6} \mathrm{O}_{14}$ (in small amount) and $\mathrm{BaTiO}_{3}$ based solid solution (in considerable amount) appeared. Simultaneously, the share of $\mathrm{Bi}_{12} \mathrm{TiO}_{2}$ decreased and the share of $\left(\mathrm{Na}_{0.5} \mathrm{Bi}_{0.5}\right) \mathrm{TiO}_{3}$-based solid solution increased.

Calcination at $850^{\circ} \mathrm{C}$ led to disappearance of the intermediate compound $\mathrm{NaBiTi}_{6} \mathrm{O}_{14}$ and after calcination at $900^{\circ} \mathrm{C} \mathrm{Bi}_{12} \mathrm{TiO}_{20}$ also disappeared.

NBT-based solid solution was the predominant product after calcination at $1000^{\circ} \mathrm{C}$ for $1 \mathrm{~h}$. Based on the results of the $\mathrm{X}$-ray analysis, we concluded that the indium and niobium ions forming the $\left(\operatorname{In}_{0.5} \mathrm{Nb}_{0.5}\right)$ complex "got into" $B$-sites of the perovskite crystal lattice almost completely. $\mathrm{BaTiO}_{3}$ based solid solution and $\mathrm{In}_{2} \mathrm{O}_{3}$ were also present, but in small amounts (of the order of $2-3 \%$ ).

The completion of formation of a single-phase $\left[\left(\mathrm{Na}_{0.5} \mathrm{Bi}_{0.5}\right)_{0.8} \mathrm{Ba}_{0.2}\right] \mathrm{Ti}_{0.8}\left(\mathrm{In}_{0.5} \mathrm{Nb}_{0.5}\right)_{0.2} \mathrm{O}_{3}$ solid solution took place at the temperatures in the interval of $1050-1100^{\circ} \mathrm{C}$. 


\section{6. $\left[\left(\mathrm{Na}_{0.5} \mathrm{Bi}_{0.5}\right)_{0.8} \mathrm{Ba}_{0.2}\right](\mathrm{Ti}, \mathrm{Zr}) \mathrm{O}_{3}$-based solid solutions with substitutions of $\left(\mathrm{Fe}_{0.5} \mathrm{Nb}_{0.5}\right)$}

3.6.1. Substitution of $\left(\mathrm{Fe}_{0.5} \mathrm{Nb}_{0.5}\right)$ for Ti in $\left[\left(\mathrm{Na}_{0.5} \mathrm{Bi}_{0.5}\right)_{0.8^{-}}\right.$ $\left.\mathrm{Ba}_{0.2}\right]\left[\left[\mathrm{Ti}_{0.9}\left(\mathrm{Fe}_{0.5} \mathrm{Nb}_{0.5}\right)_{0.1}\right]_{0.9} \mathrm{Zr}_{0.1} \mathrm{O}_{3}\right.$

The calcination of the mixture of starting reagents $\mathrm{Bi}_{2} \mathrm{O}_{3}$, $\mathrm{TiO}_{2}, \mathrm{Na}_{2} \mathrm{CO}_{3}, \mathrm{BaCO}_{3}, \mathrm{ZrO}_{2}, \mathrm{Fe}_{2} \mathrm{O}_{3}$ and $\mathrm{Nb}_{2} \mathrm{O}_{5}$ at $800^{\circ} \mathrm{C}$ for $6 \mathrm{~h}$ resulted in the formation of two solid solutions. One of them had the parameter of the pseudocubic crystal cell equal to $a=3.93 \AA$ (the main phase) and the crystal cell parameter of the other was $a=3.99 \AA$. A small quantity of unidentified compound was also present.

After calcination at $900^{\circ} \mathrm{C}$ for $4 \mathrm{~h}$, the solid solution with $a=3.93 \AA$ was dominant. The content of the second solid solution was $5-7 \%$. The unidentified earlier compound was absent. Bismuth titanate $\mathrm{Bi}_{12} \mathrm{TiO}_{20}$ was present as an intermediate compound (similarly to the case of substitutions of zirconium for titanium) in an amount of 7-10\%.

Complete formation of the single-phase solid solution occurred at $1100^{\circ} \mathrm{C}$.

\subsubsection{Substitution of $\left(\mathrm{Fe}_{0.5} \mathrm{Nb}_{0.5}\right)$ for $\mathrm{Zr}$ in $\left[\left(\mathrm{Na}_{0.5} \mathrm{Bi}_{0.5}\right)_{0.8^{-}}\right.$ $\left.\mathrm{Ba}_{0.2}\right]\left\{\left(\mathrm{Ti}_{0.9}\left[\mathrm{Zr}_{0.08}\left(\mathrm{Fe}_{0.5} \mathrm{Nb}_{0.5}\right)_{0.02}\right]_{0.1}\right\} \mathrm{O}_{3}\right.$}

The calcination of mixture of $\mathrm{Bi}_{2} \mathrm{O}_{3}, \mathrm{TiO}_{2}, \mathrm{Na}_{2} \mathrm{CO}_{3}, \mathrm{BaCO}_{3}$, $\mathrm{ZrO}_{2}, \mathrm{Fe}_{2} \mathrm{O}_{3}$ and $\mathrm{Nb}_{2} \mathrm{O}_{5}$, corresponding to the composition $\left[\left(\mathrm{Na}_{0.5} \mathrm{Bi}_{0.5}\right)_{0.8} \mathrm{Ba}_{0.2}\right]\left\{\left(\mathrm{Ti}_{0.9}\left[\mathrm{Zr}_{0.08}\left(\mathrm{Fe}_{0.5} \mathrm{Nb}_{0.5}\right)_{0.02}\right]_{0.1}\right\} \mathrm{O}_{3}\right.$, at $800^{\circ} \mathrm{C}$ for $6 \mathrm{~h}$ resulted in the formation of a solid solution with the perovskite structure and the crystal cell parameter $a=3.93 \AA$ as the main phase. The perovskite solid solution with the cell parameter $a=3.99 \AA$ was present in a larger quantity than in the case of the substitution for titanium. Additionally, a significant quantity of the intermediate phase $\mathrm{Bi}_{12} \mathrm{TiO}_{20}$ was detected.

After calcination at $900^{\circ} \mathrm{C}$ for $4 \mathrm{~h}$, three solid solutions with lattice parameters $a=3.89 \AA$ (in amounts of about 5\%), $a=3.93 \AA$ (in amounts of 90\%) and $a=4.00 \AA$ (about 5\%) were present in the reaction product. Traces of bismuth titanate $\mathrm{Bi}_{12} \mathrm{TiO}_{20}$ were also observed in the reaction product as an intermediate compound.

Formation of the single-phase compound occurred at $1100^{\circ} \mathrm{C}$.

We carried out substitutions of the $\left(\mathrm{Fe}_{0.5} \mathrm{Nb}_{0.5}\right)$ ion complex for titanium and zirconium ions in the same $\left[\left(\mathrm{Na}_{0.5} \mathrm{Bi}_{0.5}\right)_{0.8} \mathrm{Ba}_{0.2}\right]\left(\mathrm{Ti}_{0.9} \mathrm{Zr}_{0.1}\right) \mathrm{O}_{3}$ solid solution alternatively. This ion complex has average ionic radius greater than the ionic radius of titanium but smaller than the ionic radius of zirconium. In subsection 3.6.1, the substitution of this complex for titanium is considered and in subsection 3.6.2, this ion complex is used to substitute zirconium. The average ionic radius of the $\left(\mathrm{Fe}_{0.5} \mathrm{Nb}_{0.5}\right)$ ion complex is greater than the ionic radius of titanium. As a result, the stability of the FE state is lowered with respect to the stability of the AFE state. This leads to a decrease of the temperature of the FE-AFE phase transition. In the second case, the stability of the FE phase with respect to the stability of the AFE phase increases since the ion radius of the $\left(\mathrm{Fe}_{0.5} \mathrm{Nb}_{0.5}\right)$ ion complex is smaller than the ionic radius of zirconium. The temperature of the FE-AFE transition increases in this case. The shift of the transition temperatures will be discussed in the next section.

\subsection{Concluding remarks for Sec. 3}

Synthesis of all investigated NBT-based compounds with substitutions for Ti in the $B$-sites of the crystal lattice takes place completely with formation of single-phase final solid solutions. The only exception are the solid solutions obtained by the substitutions of zirconium for titanium in "a pure" NBT.

Introduction of barium ions that substitutes (NaBi) complex in the $A$-sites of the crystal lattice enables to produce a single-phase final product of the solid-state synthesis, namely, $\left[\left(\mathrm{Na}_{0.5} \mathrm{Bi}_{0.5}\right)_{0.8} \mathrm{Ba}_{0.2}\right]\left(\mathrm{Ti}_{1-y} \mathrm{Zr}_{y}\right) \mathrm{O}_{3}$ solid solutions.

In our opinion, it is related to the fact that $\mathrm{Zr}^{4+}$ ions have larger size compared to the size of $\mathrm{Ti}^{4+}$ ions and, thus, there is not enough space for zirconium ions in the octahedral sites of NBT. Substitutions of $\mathrm{Ba}^{2+}$ ions for $\left(\mathrm{Na}_{0.5} \mathrm{Bi}_{0.5}\right)^{2+}$ ion complex leads to the increase of the size of the perovskite elementary cell and as a consequence to the increase of the inside-octahedral space. In this case, zirconium ion can settle inside the lattice completely and in the end of the synthesis process, the single-phase solid solution is produced.

\section{Effect of Ion Substitutions on Phase Transformations}

Due to the situation that the $\left[\left(\mathrm{Na}_{0.5} \mathrm{Bi}_{0.5}\right)_{1-x} \mathrm{Ba}_{x}\right] \mathrm{TiO}_{3}$ solid solutions with barium content greater than $15 \%$ are not systematically studied, the question about existence of the phase transition between the FE and AFE phases in the $\left[\left(\mathrm{Na}_{0.5} \mathrm{Bi}_{0.5}\right)_{0.8} \mathrm{Ba}_{0.2}\right] \mathrm{TiO}_{3}$ solid solution (that was chosen as a base compound in our studies) can arise. In connection with this, it makes most sense to comment on the way of the identification of phase states.

It appears that the first study of the "composition-temperature" phase diagram of the phase states in the $\left[\left(\mathrm{Na}_{0.5} \mathrm{Bi}_{0.5}\right)_{1-x} \mathrm{Ba}_{x}\right] \mathrm{TiO}_{3}$ system of solid solutions was presented in Ref. 18. The phase diagram presented there was quite schematic and reflected only general tendencies in formation of different phase states in this series of solid solutions.

The phase diagram published in Ref. 9 is the most complete phase diagram for ceramic samples with barium titanate content up to $15 \%$. The region of the AFE states is shown to be located in the temperature interval between the regions of the FE and paraelectric (PE) states. The authors of Ref. 9 also indicated the presence of additional lines inside the AFE region of the phase diagram. The nature of these lines as well as whether these lines were actual phase boundaries were not discussed. It is possible that the presence of these lines is a peculiarity of the AFE region proper but it is also possible that this is a consequence of use of ceramic samples. 
The phase diagram for single crystals of the same series of $\left[\left(\mathrm{Na}_{0.5} \mathrm{Bi}_{0.5}\right)_{1-x} \mathrm{Ba}_{x}\right] \mathrm{TiO}_{3}$ solid solutions was specified in Ref. 21. The authors of Ref. 21 carried out the high precision study of the crystal structure by synchrotron radiation as well as dielectric measurements on single crystals in a wide temperature interval. They demonstrated the existence of the intermediate AFE states. It has to be noted that making measurements on single crystals, they did not find any additional transitions within this intermediate region of the AFE states.

Summarizing all above-said one can conclude that the absolute majority of authors pointed out the presence of the intermediate region of the AFE states (separating the regions of the FE and PE states) in solid solutions with barium content up to $15 \%$.

Since the practical interest in compounds under consideration is conditioned by the manufacturing of materials with large values of the piezoelectric coefficient, the main attention in the literature was devoted to the solid solutions with compositions within the MPB region. There are few publications on investigations of solid solutions with larger content of barium titanate.

As can be seen in the phase diagram given in Ref. 9, the boundaries of the AFE region do not collapse at $x=15 \%$ and the AFE region being a border region between the FE and PE states is extended toward the larger concentrations of barium titanate. In particular, the whole series of solid solutions with the barium titanate content up to $90 \%$ was investigated in Ref. 21. One of the results of this study was obtained on the solid solution with $20 \%$ of barium titanate. It was shown that besides the PE phase transition at $300^{\circ} \mathrm{C}$, there exists a phase transition in the region $160-170^{\circ} \mathrm{C}$ located at the continuation of the line of the FE-AFE phase transitions, which is indicated in the majority of publications.

Concluding the discussion of this subject, we want to draw attention to Refs. 19, 22 and 23, which have the phase diagrams of phase states for solid solutions with the barium titanate content up to $20 \%$. The authors indicated the presence of the two different phase transitions in the solid solution with $20 \%$ of barium titanate. These transitions are the high-temperature phase transition into the PE state and the low-temperature transition between the FE and AFE states (see the inset in Fig. 4). ${ }^{19}$

We did not relay just on these literature data and carried out measurements of temperature dependencies of dielectric parameters in an applied electric field.

The temperature dependencies of the imaginary part of dielectric constant, $\varepsilon^{\prime \prime}$, in the vicinity of the low-temperature phase transition for two solid solutions with $20 \%$ of barium are shown in Fig. 4. The curves (1) correspond to the solid solution without titanium substitution and the curves (2) correspond to the case when $5 \%$ substitution of titanium by zirconium took place. The measurements were carried out without applied electric field (a) and in its presence (b) in both cases.

The temperature of the low-temperature transition (which we attribute to the phase transition between the FE

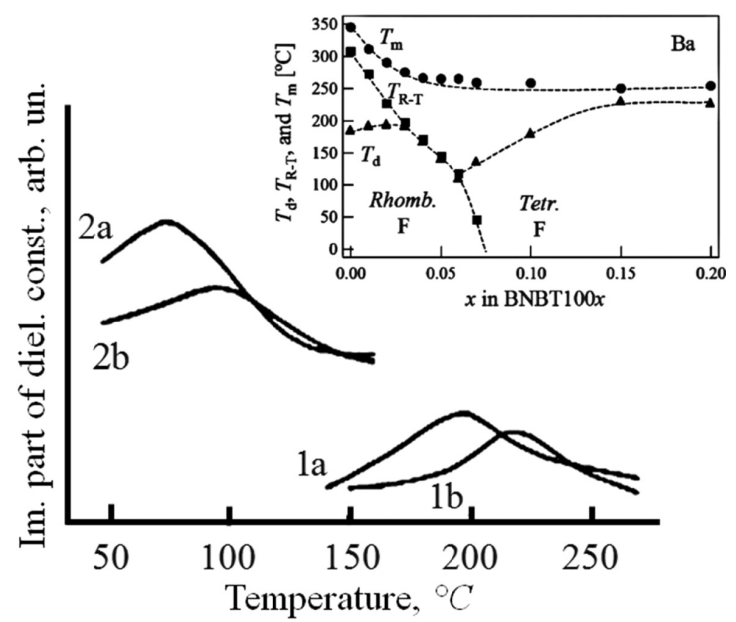

Fig. 4. Imaginary part of the dielectric constant versus temperature for the $\left.\left(\mathrm{Na}_{0.5} \mathrm{Bi}_{0.5}\right)_{0.80} \mathrm{Ba}_{0.20}\right]\left(\mathrm{Ti}_{1-y} \mathrm{Zr}_{y}\right) \mathrm{O}_{3}$ solid solutions (a) without external electric field and (b) under the action of an external electric field of $1100 \mathrm{~V} / \mathrm{mm}$. Zr-content $(y): 1-0.00,2-0.05$. The "composition-temperature" phase diagram for $\left[\left(\mathrm{Na}_{0.5} \mathrm{Bi}_{0.5}\right)_{1-x^{-}}\right.$ $\left.\mathrm{B}_{x}\right] \mathrm{TiO}_{3}$ series from Ref. 16 is shown in the insert.

and AFE states) increased when the value of applied electric field increased. The rate of the temperature increase was 19 degree $/(\mathrm{kV} / \mathrm{mm})$. At the same time the temperature of the high-temperature transition decreased at the rate of 1.5 degree/(kV/mm). The anomaly of the $\varepsilon^{\prime \prime}(T)$ dependence near the PE transition is much less pronounced and it cannot be visible on a scale of Fig. 4. Such changes of the characteristic phase transition temperatures with an applied electric field are specifically typical for the region of the AFE ordering. ${ }^{12,24}$

The rate of the temperature displacement for the lowtemperature phase transition (the FE-AFE transition) in an external field for our solid solutions is close to the values of the rate of displacement of the FE-AFE transition for the $\left(\mathrm{Na}_{0.5} \mathrm{Bi}_{0.5}\right) \mathrm{TiO}_{3}-\mathrm{BaTiO}_{3}$ solid solutions with small content of barium titanate ${ }^{10}$ (in which the AFE phase has been explicitly identified).

Figure 5 shows the temperature dependencies of the real part of the dielectric constant, $\varepsilon^{\prime}$, for ceramic samples of the $\left[\left(\mathrm{Na}_{0.5} \mathrm{Bi}_{0.5}\right)_{0.80} \mathrm{Ba}_{0.20}\right]\left(\mathrm{Ti}_{1-y} \mathrm{Zr}_{y}\right) \mathrm{O}_{3}$ solid solutions with different zirconium content. Two anomalies of the $\varepsilon^{\prime}(T)$ dependence are clearly visible. The first of them (the lowtemperature one) corresponds to the FE-AFE phase transition and the second one corresponds to the transition from the AFE (nonpolar) phase to the PE phase. The low-temperature phase transition is also accompanied by an anomaly in the temperature dependence of the imaginary part of the dielectric constant, $\varepsilon^{\prime \prime}$, (Fig. 5). The temperature, at which the lowtemperature phase transition occurs, significantly decreases when the zirconium content in the solid solution increases. As one can see, the effect of zirconium content on the position of the high-temperature phase transition is weak.

The study of the crystal structure of solid solutions showed that an increase in content of the substituting element 

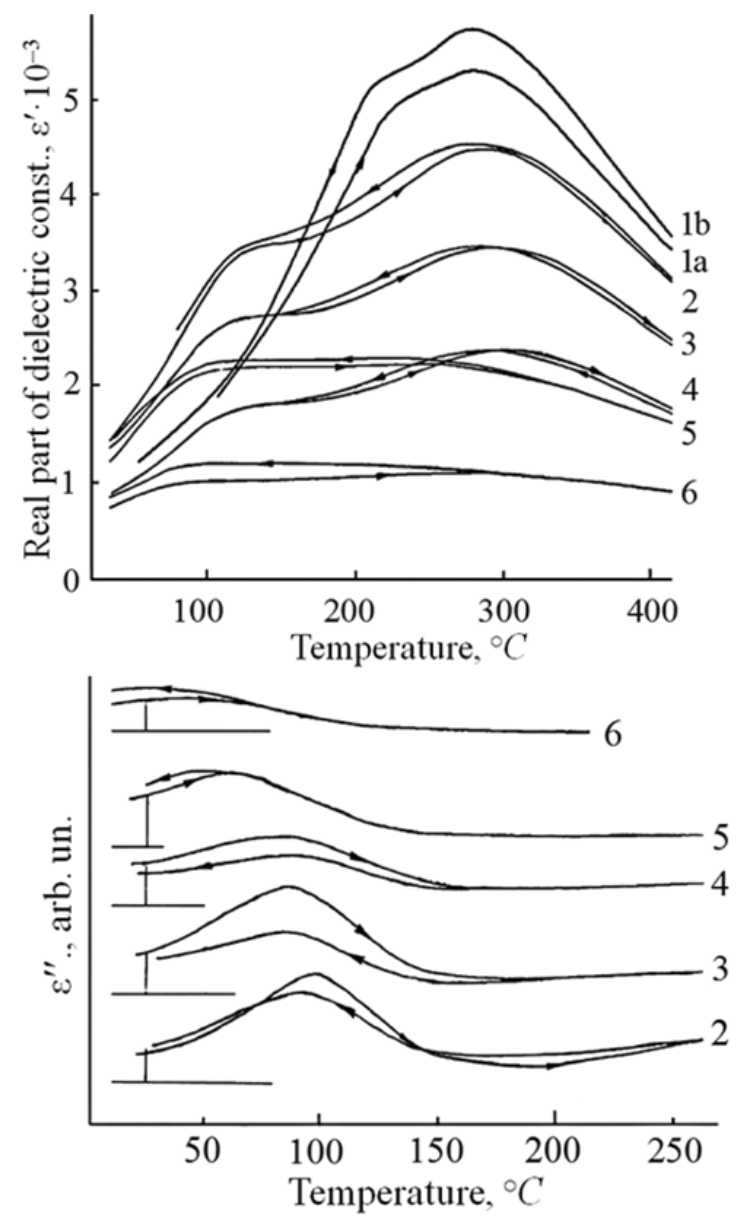

Fig. 5. Temperature dependence of the real, $\varepsilon^{\prime}$, (at the top of the figure) and imaginary, $\varepsilon^{\prime \prime}$ (at the bottom of the figure) parts of dielectric constant for the $\left[\left(\mathrm{Na}_{0.5} \mathrm{Bi}_{0.5}\right)_{0.80} \mathrm{Ba}_{0.20}\right]\left(\mathrm{Ti}_{1-y} \mathrm{Zr}_{y}\right) \mathrm{O}_{3}$ solid solutions. Zr-content, (y): $1-0.00$ (a - unpoled, b - poled samples), $2-0.025,3-0.05,4-0.10,5-0.15,6-0.20$.

led to a linear increase in the size of the unit cell. Figure 6 shows the dependence of crystal lattice parameter, calculated in pseudocubic approximation, on zirconium content. As one can see, linear dependence is performed with good accuracy.

Similar results were obtained for solid solutions with substitutions of tin for titanium. The temperature of the transition between the FE and AFE states decreased with an increase in tin content. The size of the crystal cell tended to increase with an increase of tin concentration (Fig. 6). Since the size of the tin ion is smaller than that of zirconium ion, the rate of increase in the lattice parameter in the case of substitutions of tin for titanium is smaller. The phase transition temperature between the two dipole-ordered states (FE and AFE) decreased when the tin content increased.

Effect of the zirconium and tin ions on the relative stability of the FE and AFE states can be explained on the basis of size effect, as it has been done in relation to the stability of the same phases in the PZT-based solid solutions. The tolerance factor $t=\left(R_{A}+R_{O}\right) / \sqrt{ } 2\left(R_{B}+R_{O}\right)$ is usually used as an estimation parameter. In the PZT-based solid solutions, the

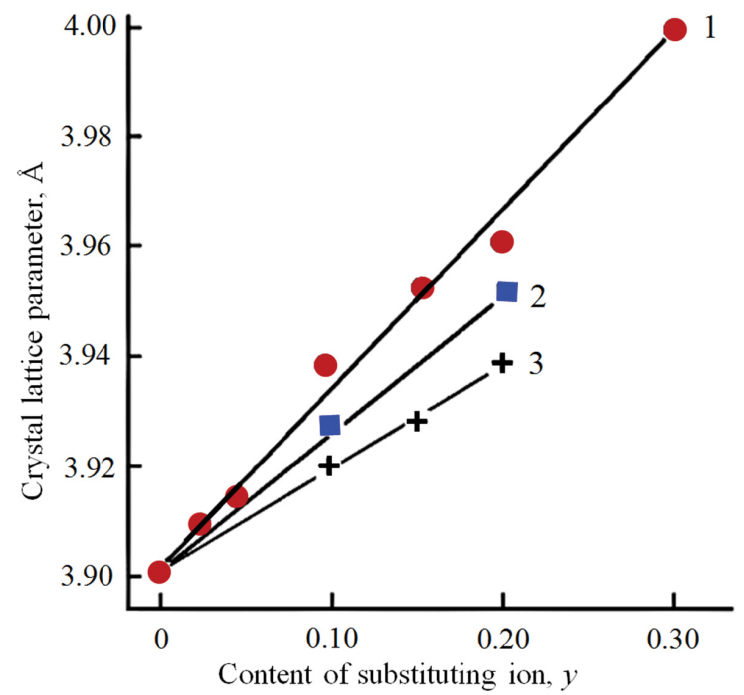

Fig. 6. Dependence of the crystal lattice parameter on the content of substituting element, $B$, in $\left.\left(\mathrm{Na}_{0.5} \mathrm{Bi}_{0.5}\right)_{0.80} \mathrm{Ba}_{0.20}\right]\left(\mathrm{Ti}_{1-y} \mathrm{~B}_{y}\right) \mathrm{O}_{3}$. Subsisting elements: $1-\mathrm{Zr}, 2-\mathrm{Sn}, 3-\left(\mathrm{Fe}_{1 / 2} \mathrm{Nb}_{1 / 2}\right)$.

FE state is a stable state at large values of $t(t>0.9090)$, for small values of $t(t<0.9080)$ the stable state is the AFE one. ${ }^{25} \mathrm{An}$ increase in the ionic radius of the $B$-ion leads to a decrease of the $t$-factor. Just this effect has been observed in the case of substitutions of the zirconium (as well as the tin) for the titanium in the NBT-based solid solutions. Such conclusion has been also confirmed by the results obtained during the investigation of solid solutions with substitutions of the $\mathrm{Ti}^{4+}$ ion by the $\left(\mathrm{In}_{1 / 2} \mathrm{Nb}_{1 / 2}\right)^{4+}$ complex. The average ion radius of the latter is larger than the radius of $\mathrm{Ti}^{4+}$ ion. Therefore, the stability of the FE state was lowered against the stability of the AFE state when the content of $\left(\mathrm{In}_{1 / 2} \mathrm{Nb}_{1 / 2}\right)^{4+}$ increased, and the temperature of the FEAFE phase transition decreased.

To verify the influence of the proposed dimensional mechanism of ionic substitutions on the FE to AFE phase transition in NBT-based solid solutions, we carried out substitutions of zirconium or titanium ions by the $\left(\mathrm{Fe}_{1 / 2} \mathrm{Nb}_{1 / 2}\right)$ complex as the next stage of our investigations. This ion complex has the same valence as the replaceable ions. Substitutions were carried out with respect to the following schemes: $\left[\left(\mathrm{Na}_{0.5} \mathrm{Bi}_{0.5}\right)_{0.80} \mathrm{Ba}_{0.20}\right]\left\{\left[\left(\mathrm{Ti}_{0.90}\left(\mathrm{Fe}_{0.5} \mathrm{Nb}_{0.5}\right)_{0.1}\right)\right]_{0.90^{-}}\right.$ $\left.\left.\mathrm{Zr}_{0.10}\right]\right\} \mathrm{O}_{3}$ and $\left[\left(\mathrm{Na}_{0.5} \mathrm{Bi}_{0.5}\right)_{0.80} \mathrm{Ba}_{0.20}\right]\left\{\left(\mathrm{Ti}_{0.90}\left[\mathrm{Zr}_{0.08}\right.\right.\right.$ $\left.\left.\left(\mathrm{Fe}_{0.5} \mathrm{Nb}_{0.5}\right)_{0.02}\right]_{0.10}\right\} \mathrm{O}_{3}$. In the first case, the average ionic radius of the $\left(\mathrm{Fe}_{1 / 2} \mathrm{Nb}_{1 / 2}\right)$ complex is greater than the radius of the substituted titanium ion; in the second case, the average ionic radius of the $\left(\mathrm{Fe}_{1 / 2} \mathrm{Nb}_{1 / 2}\right)$ complex is smaller than the radius of the substituted zirconium ion.

Figure 7 shows the temperature dependencies of the imaginary part of the dielectric constant for solid solutions with the compositions shown above. As one can see, the stability of the AFE state with respect to the FE state increases in the first case (in full agreement with the proposed model), and the temperature of the FE $\rightarrow$ AFE transition 


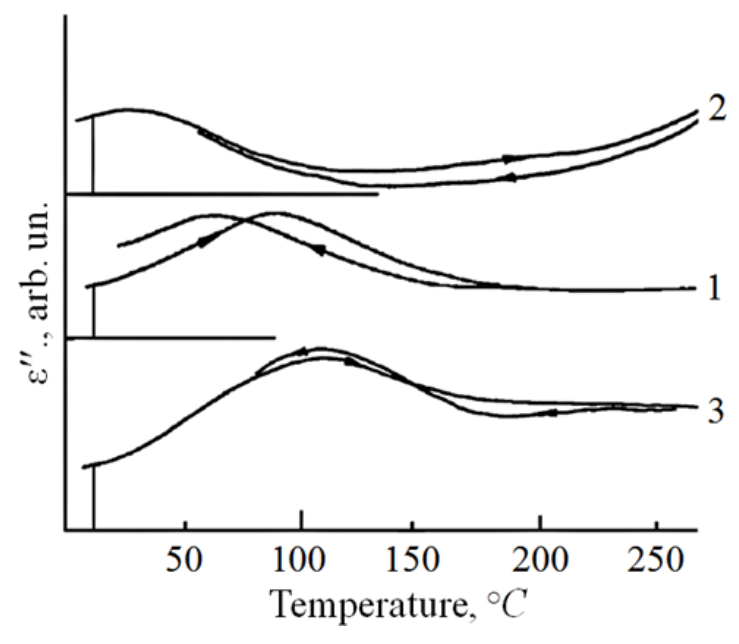

Fig. 7. Imaginary part of dielectric constant, $\varepsilon^{\prime \prime}$, versus temperature for the $\left.\left(\mathrm{Na}_{0.5} \mathrm{Bi}_{0.5}\right)_{0.80} \mathrm{Ba}_{0.20}\right]\left(\mathrm{Ti}_{0.9} \mathrm{Zr}_{0.10}\right) \mathrm{O}_{3}$ based solid solutions. 1 - without substitutions for $\mathrm{Ti}$ and $\mathrm{Zr}$ in the $B$-sites, 2 - with substitution of $\left(\mathrm{Fe}_{1 / 2} \mathrm{Nb}_{1 / 2}\right)$-complex for Ti according the chemical formula $\left.\left(\mathrm{Na}_{1 / 2} \mathrm{Bi}_{1 / 2}\right)_{0.80} \mathrm{Ba}_{0.210}\right]\left[\left\{\left[\mathrm{Ti}_{0.9}\left(\mathrm{Fe}_{1 / 2} \mathrm{Nb}_{1 / 2}\right)_{0.10}\right]_{0.90} \mathrm{Zr}_{0.10}\right\}-\right.$ $\mathrm{O}_{3}, 3$ - with substitution of $\left(\mathrm{Fe}_{1 / 2} \mathrm{Nb}_{1 / 2}\right)$-complex for $\mathrm{Zr}$ according the chemical formula $\left[\left(\mathrm{Na}_{1 / 2} \mathrm{Bi}_{1 / 2}\right)_{0.80} \mathrm{Ba}_{0.20}\right]\left\{\mathrm{Ti}_{0.9}\left[\mathrm{Zr}_{0.08^{-}}\right.\right.$ $\left.\left.\left(\mathrm{Fe}_{1 / 2} \mathrm{Nb}_{1 / 2}\right)_{0.02}\right]_{0.10}\right\} \mathrm{O}_{3}$.

decreases. In the second case, there is an increase of the FE state stability and the temperature of the FE $\rightarrow$ AFE phase transition increases.

\section{Conclusions}

Synthesis of the NBT-based solid solutions with substitutions of the Ti ions is a multi-step process which is accompanied by the formation of a number of intermediate phases.

The single-phase solid solutions have been obtained when the calcination temperatures were in the range of $1000^{\circ} \mathrm{C}$ and higher.

The substitution of titanium by zirconium, tin and $\left(\mathrm{In}_{0.5} \mathrm{Nb}_{0.5}\right)$ and $\left(\mathrm{Fe}_{0.5} \mathrm{Nb}_{0.5}\right)$ complexes has led to a decrease of the tolerance factor and to an increase of the stability of the AFE phase relative to the stability of the FE phase.

The substitution of zirconium by the $\left(\mathrm{Fe}_{0.5} \mathrm{Nb}_{0.5}\right)$ complex has led to an increase of the tolerance factor and to an increase of the FE phase stability relative to the stability of the AFE phase.

Increase in concentration of ions substituting Ti ions has led to a linear increase in the size of the crystal unit cell. At the same time, substitutions for Ti-ions tend to decrease the tolerance factor due to larger ionic radii of the $B$-site ion. The changes in the relative stability of the FE and AFE phases have been in concert with variation of the tolerance factor of solid solution.

\section{References}

${ }^{1}$ P. K. Panda, Review: Environmental friendly lead-free piezoelectric materials, J. Mater. Sci. 44, 5049 (2009).
${ }^{2}$ J. Rödel, W. Jo, K. T. P. Seifert, E. M. Anton, T. Granzow and D. Damjanovic, Perspective on the development of lead-free piezoceramics, J. Am. Ceram. Soc. 92, 1153 (2009).

${ }^{3}$ Y.-Q. Lu and Y.-X. Li, A review on lead-free piezoelectric ceramics studies in China, J. Adv. Dielectr. 1, 269 (2011).

${ }^{4}$ S. Priya and S. Nahm (eds.), Lead-Free Piezoelectrics (Springer, New York, Dordrecht, Heidelberg, London, 2012).

${ }^{5}$ I. Coondoo, N. Panwar and A. Kholkin, Lead-free piezoelectrics: Current status and perspectives, J. Adv. Dielectr. 3, 130002 (2013).

${ }^{6}$ J. Wu, D. Xiao and J. Zhu, Potassium-sodium niobate lead-free piezoelectric materials: Past, present, and future of phase boundaries, Chem. Rev. 115, 2559 (2015).

${ }^{7}$ R. R. McQuade and M. R. Dolgos, A review of the structureproperty relationships in lead-free piezoelectric $(1-x)$ $\mathrm{Na}_{0.5} \mathrm{Bi}_{0.5} \mathrm{TiO}_{3}-(x) \mathrm{BaTiO}_{3}$, J. Solid State Chem. 242, Pt. 2, 140 (2016).

${ }^{8}$ H. D. Li, C. D. Feng and W. L. Yao, Some effects of different additives on dielectric and piezoelectric properties of $\left(\mathrm{Bi}_{1 / 2} \mathrm{Na}_{1 / 2}\right) \mathrm{TiO}_{3}-\mathrm{BaTiO}_{3}$ morphotropic phase boundary composition, Mater. Lett. 58, 1194 (2004).

${ }^{9}$ F. Cordero, F. Craciun, F. Trequattrini, E. Mercadelli and C. Galassi, Phase transitions and phase diagram of the ferroelectric perovskite $(1-x)\left(\mathrm{Na}_{0.5} \mathrm{Bi}_{0.5}\right) \mathrm{TiO}_{3}-x \mathrm{BaTiO}_{3}$ by anelastic and dielectric measurements, Phys. Rev. B 81, 144124 (2010).

${ }^{10}$ E. Sapper, N. A. Novak, W. Jo, T. Granzow and J. Rödel, Electric field - temperature phase diagram of the ferroelectric relaxor system $(1-x)\left(\mathrm{Na}_{0.5} \mathrm{Bi}_{0.5}\right) \mathrm{TiO}_{3}-x \mathrm{BaTiO}_{3}$ doped with manganese, J. Appl. Phys. 115, 194104 (2014).

${ }^{11}$ B. Jaffe, W. R. Cook and H. Jaffe, Piezoelectric Ceramics (Academic Press, New York, 1971).

${ }^{12}$ M. E. Lines and A. M. Glass, Principles and Application of Ferroelectrics and Related Materials (Clarendon Press, Oxford, 1977).

${ }^{13}$ L. K. Kumari, K. Prasad and R. N. P. Choudhary, Impedance analysis of $\left(\mathrm{Na}_{0.5} \mathrm{Bi}_{0.5}\right)\left(\mathrm{Zr}_{0.25} \mathrm{Ti}_{0.75}\right) \mathrm{O}_{3}$ ceramic, Indian J. Eng. Mater. Sci. 15, 147 (2008).

${ }^{14}$ C. Peng, J.-F. Li and W. Gong, Preparation and properties of $\left(\mathrm{Bi}_{1 / 2} \mathrm{Na}_{1 / 2}\right) \mathrm{TiO}_{3}-\mathrm{Ba}(\mathrm{Ti}, \mathrm{Zr}) \mathrm{O}_{3}$ lead-free piezoelectric ceramics, Mater. Lett. 59, 1576 (2005).

${ }^{15} \mathrm{~B}$. Tilak, Ferroelectric relaxor behavior and spectroscopic properties of $\mathrm{Ba}^{2+}$ and $\mathrm{Zr}^{4+}$ modified sodium bismuth titanate, Am. J. Mater. Sci. 2, 110 (2012).

${ }^{16} \mathrm{~J}$. Glaum, H. Simons, M. Acosta and M. Hoffman, Tailoring the piezoelectric and relaxor properties of $\left(\mathrm{Bi}_{1 / 2} \mathrm{Na}_{1 / 2}\right) \mathrm{TiO}_{3}-\mathrm{BaTiO}_{3}$ via zirconium doping, J. Am. Ceram. Soc. 96, 2881 (2013).

${ }^{17}$ E. A. Zereffa and A. V. Prasadarao, Effect of zirconium substitution on the electrical properties of ferroelectric $\left(\mathrm{Bi}_{0.5} \mathrm{Na}_{0.5}\right)_{0.94} \mathrm{Ba}_{0.06} \mathrm{TiO}_{3}$ ceramics, Int. Res. J. Pure Appl. Chem. 2, 130 (2012).

${ }^{18}$ T. Takenaka, K. Maruyama and K. Sakata, $\left(\mathrm{Bi}_{1 / 2} \mathrm{Na}_{1 / 2}\right) \mathrm{TiO}_{3}-$ $\mathrm{BaTiO}_{3}$ system for lead-free piezoelectric ceramics, Jpn. J. Appl. Phys., 30 Part 1, 2236 (1991).

${ }^{19}$ Y. Hiruma, Y. Watanabe, H. Nagata and T. Takenaka, Phase transition temperatures of divalent and trivalent ions substituted $\left(\mathrm{Bi}_{1 / 2} \mathrm{Na}_{1 / 2}\right) \mathrm{TiO}_{3}$ ceramics, Key Eng. Mater. 350, 93 (2007).

${ }^{20}$ R. D. Shannon and C. T. Prewitt, Effective ionic radii in oxides and fluorides, Acta Crystallogr. B 25, 925 (1969).

${ }^{21}$ W. Ge, C. Luo, Q. Zhang, Y. Ren, J. Li, H. Luo and D. Viehland, Evolution of structure in $\left(\mathrm{Na}_{0.5} \mathrm{Bi}_{0.5}\right) \mathrm{TiO}_{3}$ single crystals with $\mathrm{BaTiO}_{3}$, Appl. Phys. Lett. 105, 162913 (2014). 
${ }^{22}$ M. Dunce, E. Birks, M. Antonova, A. Plaude, R. Ignatans and A. Sternberg, Structure and dielectric properties of $\mathrm{Na}_{1 / 2} \mathrm{Bi}_{1 / 2} \mathrm{TiO}_{3}-$ $\mathrm{BaTiO}_{3}$ solid solutions, Ferroelectrics 447, 1 (2013).

${ }^{23}$ Y. Hiruma, K. Yoshii, H. Nagata and T. Takenaka, Investigation of phase transition temperatures in $\left(\mathrm{Bi}_{1 / 2} \mathrm{Na}_{1 / 2}\right) \mathrm{TiO}_{3}-$ $\left(\mathrm{Bi}_{1 / 2} \mathrm{~K}_{1 / 2}\right) \mathrm{TiO}_{3}$ and $\left(\mathrm{Bi}_{1 / 2} \mathrm{Na}_{1 / 2}\right) \mathrm{TiO}_{3}-\mathrm{BaTiO}_{3}$ lead-free piezoelectric ceramics by electrical measurements, Ferroelectrics 346, 114 (2007).
${ }^{24}$ G. Shirane, E. Savaguchi and Y. Tagaki, Dielectric properties of lead zirconate, Phys. Rev. 84, 476 (1951).

${ }^{25}$ M. Troccaz, P. Gonnard, Y. Fetiveau and L. Eyraud, Goldschmidt factor and phase diagrams of doped titanate zirconates, Ferroelectrics 14, 679 (1976). 